DOi: $10.21554 /$ hrr.042003

\title{
WORKING WITH PUPILS WITH HEARING IMPAIRMENTS IN AN INCLUSIVE EDUCATION: CHARACTERISTICS AND COMPETENCES
}

\section{Saša Stepanović ${ }^{1}$ \\ Jelena Živković}

${ }^{1}$ College of Social Work, Belgrade, Republic of Serbia

\begin{abstract}
Hearing impairment, which belongs to the group of sensory impairments, represents a permanent lowered sensitivity to sound which can have a wide range of consequences on children's life. Complete and adequate inclusion of children with hearing impairments in the educational system requires a reconsideration of the traditional approach and a reorganization of the whole teaching process. The concept of an inclusive education requires providing support and the quality of education for every pupil, regardless of their impairments or disabilities, i.e. differences from the majority of pupils. For the purpose of movement towards these goals, this article discusses some important aspects of inclusion of pupils with hearing impairment by literature review, starting from their physical and psychological characteristics. The role of the teacher and the social environment is examined, and certain technical and pedagogical recommendations are made in working with these children.
\end{abstract}

Keywords: inclusion, pupils with hearing impairments, teacher's competences, guidelines

\footnotetext{
${ }^{1}$ Correspondence to:

Saša Stepanović, College of Social Work, Republic of Serbia

Terazije 34, Belgrade, Serbia

E-mail: salenono86@gmail.com
} 


\section{INTRODUCTION}

The idea of social justice and equality in access to educational opportunities is at the heart of inclusive education that started to reform traditional schooling since the second half of the XX century. In its implementation, the constant update of knowledge about all the components of the school system is necessary. This oversight of how things are being changed in contrast to status quo, enables faster and better coordination of the basic educational elements. Undergoing such a change means getting closer to the democratic ideal of society, in which every individual has a certain place and an active contribution. With changing segregated schooling, this ideal should ensure that every child, regardless of impairments has access to high-quality schooling (Stepanović, 2018). The existing spectrum of impairments people and children can have is very wide and each of them has its own peculiarities that represent a challenge for an adaptation of the modern educational trend. In the classroom, and as a part of the school community, a child with a hearing impairment is a different child, and the way other children understand and deal with the concept of difference is one of the tasks for inclusion (Florian, 2015; Stepanović, 2016). The perspective on difference is the first step toward the appreciation of the potential of uniqueness and therefore, the encouragement of active social involvement.

In modern literature of education, the understanding of difference is not based on the universal needs, common to all children. On the contrary, it is the individual differences and special rehabilitation needs that require the organization of specific conditions and acts. The complexity of the inclusive educational system goes far beyond the simple placement of these pupils in the class (Lutfiyya, VanWalleghem, 2013; Алехина, 2016; Салимова, 2016). It affects not only children with impairments, but also their peers, parents, teachers, etc.

The aim of this article is to provide a concise review of the literature on characteristics of pupils with hearing impairment and the properties of the environment that surrounds them from early childhood. With an emphasis on the role of the teacher's competences in working with these pupils, this article gravitates toward general inclusive goals. Those goals implicate that the overcoming of obstacles is possible, as well as the realization of individuals' potential, by that very fact.

\section{PHYSICAL AND SOCIO-PSYCHOLOGICAL CHARACTERISTICS OF PUPILS WITH A HEARING IMPAIRMENT}

Acoustic experience plays a key role in all cultures (Nierling et al., 2018). In senses rankings, hearing takes second place (San Roque et al., 2015, in Nierling et al., 2018). Thus, a hearing impairment is the most common sensory impairment $-5 \%$ of population, or 3 out of 1000 newborns (Ječmenica, 2016). A hearing impairment can be defined as partial or complete inability to hear (WHO, 2015) which can have different degrees, based on the state of the healthier ear (WHO, 2016): mild (26-40dB), moderate (41$60 \mathrm{~dB})$, severe (61-80dB) and profound, including deafness ( $81 \mathrm{~dB}$ and more). It can be also classified by different criteria: innate/acquired prenatal/congenital/ perinatal/postnatal; isolated/combined; prelingual/ postlingual, progressive/nonprogressive (Ječmenica, 2016). The specificity of diagnosis gives a range of possible consequences that influence children with hearing impairment, but also their parents, school, and wider social environment.

Amongmanyphysicalandpsychologicalconsequences of hearing impairment, problems in speech come first. The hearing impairment considerably limits the child's ability to speak, to develop literacy skills and language, which lead to lower verbal communication (Ječmenica, 2016; Малярчук и др., 2018; Пешкова, 2016). These children can often have poor vocabulary, bad pronunciation, agrammatic sentences, inconsistent with the narrative context, which reflects on both writing and reading (Moeller et al., 2007). 
Since language and cognitive functions are tightly connected, impairment can have a negative influence on cognitive development in general (Jerković et al., 2010, Škrbić et al., 2013). and its specific aspects, such as unstable or shorter attention, limited abstract thinking, slower memory, strenuous understanding, lower visual perception (Lazor et al., 2008; Suzić, 2008; Škrbić et al., 2013) Intellectual development is also affected - nonverbal structures of intellect progressivly develop while verbal structures poorly develop with delayed regulative function of speach in intelectual development (Škrbić et al., 2013; Щурова, 2016). This leads to the state that a child cannot fully follow narratives and participate in what is happening around him (Jerković et al., 2010).

Additionally, the aforementioned factors are usually accompanied with secondary, potentially more serious effects on personal and emotional development, and social integration (Ječmenica, 2016; Škrbić et al., 2013; Пешкова, 2016). The main problem of pupils with hearing impairment is the interaction with others as it takes great effort for them to comprehend the speech and the wider context. This leads to communication barriers and limited communicative activity, which cause other psychological problems: lower developed and less stable mental system, delayed general personal development, limited knowledge and activity, limited social experience and interpersonal relationships, strong need to communicate (Двуреченская, 2018, Малярчук и др., 2018; Пешкова, 2016). Limited interaction with social environment, especially the peers, can result in social isolation (Avramidis, 2010, Nierling etal., 2018; Салимова, 2016, Полешко, 2018). Along with the suffering difficulty of socialization and handling the school environment, it may seriously compromise the quality of life of an individual with a hearing impairment (Fellinger et al., 2008; Hintermair, 2011; Škrbić et al., 2013; Речицкая \& Хедхуд, 2014). These factors primarily lie in the environment that does not recognize these difficulties or does not provide empathy, support and the opportunity for equal participation in various activities (Jerković et al., 2010; Mackenzie \& Smith, 2009). Hearing is not a visible impairment and can pass unnoticed by the environment, even specialists (Nierling et al., 2018). Indirectly, such an environment signifies insufficient readiness and organization of the system for the practice of inclusion, and it can leave deeper consequences (Vilotić, 2014; Stepanović, 2018). Often, pupils with a hearing impairment are stigmatized with prejudice and stereotypes, because the peculiarities of the impairment and its outcomes are hard for children without it to understand (Jerković et al., 2010; Данилова, 2017). In order to avoid intolerance and to fit in, these pupils tend to or to deny their impairment, which lead to them not seeking for help (Nierling et al., 2018). Despite the fact that this tendency has a protective purpose, it leads to a faulty understanding of the nature of impairment and negatively influences the identity of a pupil. The lack of understanding and social stigma towards these children (from peers, teachers and school in general), cause deformation in their personality: low selfesteem and self-respect, social-emotional immaturity, insufficient independence and responsibility, delayed moral development, low motivation, lack of interests, negative attitudes towards themselves and the people around them, rigidity and uinability to adjust, helplessness, suggestibility, high anxiety and frustration, impulsiveness, demonstrative and aggressive behaviour in attention seeking, egocentrism and fixation on their own problems, behavioral problems, violation of norms, psychotic behavior (Jerković et al., 2010; Богданова, 2018; Малярчук и др., 2018; Пешкова, 2016).

Many authors agree that in the process of inclusive education, these negative outcomes of hearing impairment on a child should be diminished. Inclusive education, due to better integration and interaction of a child with hearing impairment with its peers, positivley affects the development of interpersonal relationships, emotional well-being inside the class, increases communication skills, self-esteem and self-control and lowers psychological anxiety (Гильяно, 2018), but also develops personal qualities in pupuls with normal hearing, such as readiness to help, tolerance, and empathy (Полешко, 2018). 
Therefore, pupils with hearing impairments which are fully respected as equal by their school community can advance their communication skills, overcome physiological, psychological and social barriers, and hence, build a more positive image of their impairment and their identity as well. They become well socialized adults, deeply integrated into their community and culture, who achieved optimal level of life competences (Салимова, 2016). The established positive effects of a supporting environment indicate the necessity of investment in a system that hitherto, does not provide sufficient support.

\section{THE GUIDELINES FOR WORKING WITH CHILDREN WITH A HEARING IMPAIRMENT}

There are numerous, research-supported suggestions for schools and teachers about the organization and standards for working with children with a hearing impairment. The application of every guideline first requires a good, thorough knowledge of the child's physical state (diagnosis). That effectively discriminates between needed adjustments, because the situation is very different with a completely deaf child (e.g. where a third party that provides the translation to the sign language is present) and with a partially deaf child.

Given that the class is currently mostly teacheroriented (Stepanović, 2016), pupils with a hearing impairment should be seated as close to the teacher as possible, so that they can see them well. If the pupils' seating arrangement is circular, these pupils should be placed in the center. The most important thing is the orientation of the healthier ear to the source of sound (Ječmenica, 2016). The accessibility of sound depends on the classroom as well: the difference between "regular" classrooms and those adapted for children with hearing impairments is in good lighting and the appropriate acoustic properties (decreased ambient noise and echo) (Салимова, 2016). Visual aids that demonstrate the content (multimedia, pictures, objects, drawings, models) are highly encouraged. For the reason on their shorter attention span, potential distractors should be eliminated, which is also tied to the question of classroom discipline.

The quality of the pupil's comprehension is largely conditioned by the characteristics of the speech he listens to. Teacher's speech should be of appropriate speed, clarity, diction and loudness, with moderate pauses and movements that accompany the content. Words that are too complicated are not advisable since they can confuse the child whose hearing impairment often comes together with a less developed vocabulary. If they are necessary or appear in the speech spontaneously, the teacher should check whether the child understood the meaning, and clarify it in case he didn't. On more demanding materials, additional clarification and repetition are very notable, as well as visual illustrations (Маслова, 2014). The teacher should be careful not to cover their mouth with hands while talking, because some pupils might be using lip reading. In some occasions the usage of a microphone is appropriate. Further, the teacher should not talk and write on the board simultaneously. That interrupts the flow of information and can affect understanding.

Other guidelines a teacher can follow is motivating a pupil with hearing imparment to be more active in class, to answer and ask questions. A teacher should develop skills to maintain attention of a pupil with hearing imparment but not letting him get too tired and unconcentrated (Маслова, 2014).

Considering these suggestions, it is also a teacher's task to teach other pupils how to talk with pupils with hearing impairment. It includes informing those pupils about hearing impairment features of their classmates and motivating them to interact in different activities during and after the class (Маслова, 2014). The healthy pupils have a role of helpers, bridge-builders between a teacher and a pupil with hearing imparement. Working with healthy pupils on developing positive attitudes and readiness to communicate with pupils with hearing impairments, represents an important element of inclusive teaching (Пешкова, 2016; Салимова, 2016). In the education of pupils with impairments, we should be oriented towards the optimal development of their personality and potential. 
The key qualities of approach to children with hearing impairments are graduality, clarity, creativity, activity and patience (Lazor et al., 2008). The good guidelines and available instructions lower teachers' emotional tension and allow them to use resources for implementing different teaching methods in working with children with hearing impairment (Богданова, 2018; Маслова, 2014). Finally, consulting with the appropriate literature beyond the general guidelines, in the organization of class is advised in all situations because it narrows the teachers' attention only to the most relevant aspects of pedagogical practice.

\section{THE ROLE OF THE TEACHER}

Acording to the strengh with which inclusion influence the system of education, we can say that it represents multileveled, fundamental and systematic innovation. The contradictions that are present in traditional education are exacerbated in the inclusive education (Богданова, 2018; Салимова, 2016). Therefore, the implementation of inclusive education has many obstacles, general and specific, such as transformation of educational system, social prejudice and stereotypes in the community, lack of pedagocial and psychological support in inclusive education, lack of parental knowledge about the impairments, lack of teachers' compentences in teaching in inclusive education (Маслова, 2014).

In many studies, professional and personal readiness of a teacher to work in inclusive education is seen as the main factor for its efectiveness, and the main principle of inclusive education. Authors usually define this readiness as ,inclusive compentence“:

- complex, multilevel personal structure, an attitude towards positive professional results, the possesion and mobilization of special knowledge and skills in the ralization of an inclusive education (Алехина, 2016; Яковлева, 2013);

- complex value and cognitive-psychological formation of a person, which allows a teacher to succesfully educate children with impairments (Малярчук и др., 2018).
- a value aspect of a teacher - the formation of a basic personal culture of a teacher, professional relation towards children with impairments (Денисова, Рудакова, 2016).

- integral subjective characteristic of a teacher, based on a complex of academic, professional and sociopsychological competences, which provides work in the conditions of an inclusive education enviorment (Хитрюк, 2012)

- knowledge of specific features of pupils with impairment, methods and techniques of working with them in an inclusive education, and the formation of personal qualities that provide sustainable motivation for a teacher (Шумиловская, 2011)

- integrative personal formation, determing the ability to carry out professional functions in the process of inclusive learning, taking into account different educational needs of pupils and ensuring the inclusion of children with impairments into the environment educational institution, creacting conditions for his development and self-development (Хафизуллина, 2008)

Inclusive competence of a teacher includes different components. Hitryuk (2012) identifies two components: the first, motivational-conative component (the expresion of social attitude towards all subjects of inclusive education), which determines the second - operational components (the formation of competences) (Хитрюк, 2012). Alehina's model consists of three components: cognitive readiness (teacher's knowledge about characteristics of the development of children with impariments; motivational readiness - the readiness to interact with those children, and personal readiness - the level of emotional acceptance of those children (Алехина, 2016). Hafizulina (2008) also identifies three components: the ability of a teacher to take into account the individual characteristics of pupils in the formation of individual educational path and to ensure its implementation; the ability to objectively assess the achievement of planed learning outcomes for pupils with impairments; the ability to correct methodology and organizational aspects of teaching. 
Malyarchuk and colleagues (Малярчук и др., 2018) identify several components of teachers' competences:

- value-semantic (the teacher's understanding of the meaning of inclusion and positive attitude towards it, understanding the importance of teaching pupils with impairments about the values which are important for their personal resources);

-emotional-motivational (acceptance of pupils with impairments as equals, recognition of their rights, ability to see their positive qualities, motivation to help them to overcome difficulties in learning, bridging social distance and fighting discrimination);

- cognitive-psychological (knowledge of the specific patterns of abnormal development associated with primary, secondary and tertiary effects and barriers in teaching pupils with impairments; the ability to determine general and specific educational needs of these pupils and to activate their resources for self-development)

- operational-competence-base (the use of various kinds of information and network systems in the teaching process, the presence of positive selfidentification of pupils with impairments; their inclusion in class activities)

- reflexive-strategic (teacher's objective selfassessment of his own preparedness and the acquisition of new competencies for teaching pupils with impairments, his disposition to adopt an inclusive worldview).

Therefore, a teacher that pragmatically and consistently follows the inclusive educational goals in working with pupils that have a hearing impairment understands the nature and characteristics of specific impairments and disabilities, provides diverse kinds of support to abilities of pupils who have them, and works on their social, developmental and educational progress through the careful organization of class. While doing that, teacher should follow five principles: 1) social acceptance and support, 2) early prevention and rehabilitation, 3) stimulation and compensation, 4) functional capacity development and 5) individuality (Suzić, 2008). Teachers should evaluate their practice by following the indicators of these principles, like balancing the use of teaching methods and techniques, being certain that all pupils possess necessary materials for work and to know how to properly use them, providing all possible aids to pupils with hearing impairments, cooperating with other teachers and parents in order to adapt the class better and finally, being confident about his/her own competence.

Many studies showed that teachers are not ready (theoretically, practically and personally) to work with pupils with hearing impairment or other (Forlin, \& Chambers, 2011; Jones, West, 2009; Lutfiyya, VanWalleghem, 2013; Stepanović, 20016; Tsakiridou, Polyzopoulou, 2014; Алехина, 2016; Данилова, 2017; Денисова, Рудакова, 2016; Кабушко, Слюсарева, 2017; Малярчук и др., 2018; Маслова, 2014; Сигал, 2014). The teachers consider themselves not competent enough; they have lack of professional knowledge about inclusive education, low motivation, and difficulties associated with social-psychological characteristics and personal attitudes (low level of professionally important personal qualities for them as specialists who act in conditions of inclusive education).

This kind of attitude can be a significant obstacle for the implementation of inclusive education, i.e. it can strengthen the traditional approach in which the teacher is the most active agent that attunes only to the "average" pupil (Stepanović, 2016). Appropriate teacher training and motivation maintenance are stressed is the literature as one of the most important factors in changing such opinions and improving professional competence. Therefore, the formation of readiness for professional activity in inclusive education should be a long-term strategy, which includes a set of measures aimed at developing necessary personal and professional qualities of a teacher and other subjects in inclusive education (Данилова, 2017; Кабушко Слюсарева, 2017; Логинова и др., 2017; Салимова, 2016, Сигал, 2014):

- development and implementation of retraining and advancing qualification programs for teachers, organizing internships, master classes, conferences 
- development and implementation of psychological training programs that allow to build the ability to overcome barriers among teachers of inclusive education;

- provision of individual advisory assistance to the teachers who implement adaptive educational programs;

- development of teaching aids and recomentations for all subjects of educational environment (teachers, parents, administration), based on the contemporary research in all relevant field of pedagogy.

It is highly important to shift the focus from informing about inclusive education to the practice-oriented nature of training - mastering specific skills to carry out an inclusive educational process, because the most teachers stress out problems of implementing a teaching process and difficulties in ensuring its effectiveness (Логинова и др., 2017).

\section{CONCLUSION}

The global trend of inclusive education is one of the most important paradigm shifts in the last couple of decades that revitalized democratic ideas and placed their value as central. The social and educational inclusion of those who are marginalized contributes to the society as a whole. It enables the realization of individual potentials that everyone, regardless of the nature or degree of disabilities, possesses. In work with children who have a hearing impairment, the goal is not only their school success, but also the acquisition of communication skills that represents the irreplaceable element of a functional knowledge. Those skills include the speech itself as well as the communication norms. Having in mind the characteristics of these pupils, their vulnerability in terms of possible primary and secondary consequences, and the findings of numerous studies that emphasized environmental factors moderating these consequences, it is crucial to integrate current knowledge through the structural change of the teaching process. Providing the social network of support consisting of important figures in childrens life (parents, teachers, peers), adapting technical conditions of the classroom and nurturing a tolerant, patient social atmosphere can not only ease the pupil's engagement, but prevent many interpersonal and intrapersonal problems. In this process, the teacher has the key role, as he is the one who conducts the principles of inclusion, optimizing the learning and developmental processes in every pupil. For this reason, great efforts need to be invested into pushing the institutional, physical and psychosocial barriers of segregated schooling, so that the implementation of inclusion in real life can be possible.

\section{REFERENCES}

Avramidis, E. (2010). Social relationships of pupils with special educational needs in the mainstream primary class: peer group membership and peer assessed social behaviour. European Journal of Special Needs Education, 25, 413-429.

Fellinger, J, Holzinger, D, Sattel, H., Laucht, M. \& Goldberg, D. (2009). Correlates of mental health disorders among children with hearing impairments. Developmental Medicine and Child Neurology, 51(8), 635-641.

Florian, L. (2015). Inclusive pedagogy: a transformative approach to individual differences but can it help reduce educational inequalities? Scottish Educational Review, 47(1), 5-14.

Forlin C., \& Chambers D. (2011). Teacher preparation for inclusive education: Increasing knowledge but raising concerns. AsiaPacific Journal of Teacher Education, 39(1).

Hintermair, M. (2011). Health-related quality of life and classroom participation of deaf and hard-of-hearing students in general schools. Journal of Deaf Studies and Deaf Education, 16(2), 254-271.

Jerković I., Stanojčić S. \& Golubović Š. (2010). Internalizovani i eksternalizovani problemi dece sa oštećenim sluhom [Internalized and externalized problems of hearing impaired children]. Engrami, 32(1-2), 39-50.

Ječmenica, J. R. (2016). Ispitivanje učestalosti $i$ karakteristika senzorineuralnog oštećenja sluha usled infektivnih bolesti kod dece [The study of the frequency and characteristics of sensorineural hearing impairment due to infectious diseases in children]. Univerzitet u Beogradu: Doktorska disertacija.

Jones, P. \& West, E. (2009). Teacher education: Reflections upon teacher education in severe difficulties in the USA: shared concerns about quantity and quality. British Journal of Special Education, 36(2), 69-75.

Lazor, M., Marković, S. \& Nikolić, S. (2008). Priručnik za rad sa decom sa smetnjama u razvoju [The handbook for working with children with disabilities]. Novi Sad: Novosadski humanitarni centar. 
Lutfiyya, Z.M., \& Van Walleghem, J. (2013). Inclusive special education in Manitoba: 2001-2012. Manitoba Education Research Network (MERN). Monograph Series. Issue 6.

Mackenzie, I. \& Smith, A. (2009). Deafness - The Neglected and Hidden Disability. Annals of Tropical Medicine \& Parasitology, 103(7), 565-571

Moeller, M.P., Tomblin, B.J., Yoshinaga-Itano, C., McDonald Connor, C. \& Jerger, S. (2007). Current State of Knowledge: Language and Literacy of Children with Hearing Impairment. Ear and Hearing, 28, 740-753.

Nierling L., Maia, M.J.F., Hennen, L., Wolbring, G., Bratan, T., Kukk, P., Cas, J., Capari, L., Krieger-Lamina, J. \& Mordini, E. (2018). Assistive technologies for people with disabilities - Part II: Current and emerging technologies. Brussels: European Union.

Stepanović, S. (2016). Organizacija nastave u redovnim školama $i$ obrazovanje učenika sa senzornim oštećenjima [Organization of classes in general education schools and education of students with sensory impairments]. Univerzitet u Beogradu: Doktorska disertacija.

Stepanović, S. (2018). Inkluzija [Inclusion]. Šabac: Sumatra izdavaštvo.

Suzić, N. (2008). Uvod u inkluziju [Introduction to inclusion]. Banja Luka: HBS.

Tsakiridou, H., \& Polyzopoulou, K. (2014). Greek Teachers' Attitudes toward the Inclusion of Students with Special Educational Needs. American Journal of Educational Research, 2(4), 208-218.

Vilotić, S. (2014). Uloga i kompetencije nastavnika u inkluzivnom nastavnom procesu [The role and competences of teachers in an inclusive teaching process]. Nova Škola, 9, 76-90.

Škrbić, R., Milankov, V., Veselinović, M. \& Todorović, A. (2013). Uticaj oštećenja sluha na kvalitet života adolescenata [Impact of hearing impairment on adolescents' quality of life]. Medicinski pregled, 66(1-2), 32-39.

WHO - World Health Organization (2015). Deafness and Hearing Loss. http://www.who.int/mediacentre/factsheets/ fs300/en/.

WHO - World Health Organization (2016). Grades of Hearing Impairment. $\quad$ http://www.who.int/pbd/deafness/hearing impairment grades/en/.

Алехина, С.В. (2016). Инклюзивное образование: от политики к практике [Inclusive education: from policy to practice]. Психологическая наука и образование, 21(1), 136-145.

Богданова, Т.Г. (2018). Сурдопсихология: учебник для академического бакалавриата [Surdopsychology: а textbook for academic baccalaureate]. Москва.

Гильяно, А.С. (2018). Личностные особенности слабослышащих подростков, обучающихся в условиях общеобразовательной школы [Personal characteristics of hearing impaired teenagers learning in a general education school]. Вестник Московского государственного областного университета. Серия: Психологические науки, (4), 108-116.
Данилова, О.В. (2017). К вопросу о психологической готовности педагогов к профессиональной деятельности в условиях инклюзивного образования [То the question of the psychological readiness of teachers for professional activities in an inclusive education]. Вестник Марииского государственного университета, 11(3 (27)), 62-67.

Денисова, Р.Р. \& Рудакова Н.П. (2016). Организация профессиональной переподготовки в аспекте инклюзивного образования [Organization of professional retraining in the aspect of inclusive education]. Азимуm научных исследований: педагогика и психология, 5 (4 (17)), 111-114.

Двуреченская, С.Е. (2018). Проблема коммуникативной активности учащихся среднего школьного возраста с нарушением слуха [The problem of communicative activity of pupils of secondary school age with hearing impairment]. материальв Всероссийской научно-практической конференции «Наука и соџиум», (7-1), 47-51.

Кабушко, А.Ю. \& Слюсарёва, Е.С. (2017). Подготовка педагогических кадров для системы специального и инклюзивного образования (на примере Ставропольского государственного педагогического института) [Preparing teachers for the special and inclusive education systems (the example of the Stavropol State Pedagogical Institute)]. Вестник Костромскогогосударственного университета. Серия: Педагогика. Психология. Соччиокинетика., 23(2), 174-177.

Логинова, Е.Т., Овчинникова, Т.С. \& Баулина, М.В. (2017). Стратегия и тактика подготовки будущих педагогов к инклюзивному образованию [The strategy and tactics of preparing future teachers for inclusive education]. Специальное образование, 1, 26-29.

Малярчук, Н.Н., Плотникова, М.В., Пащенко, Е.В., \& Дыхан Л.Б. (2018). Компоненты готовности преподавателя вуза к обучению лиц разных гетерогенных групп [The components of university teacher's readiness to teach people of different heterogeneous groups]. Научные ведомости Белгородского государственного университета. Серия: Гуманитарнье науки, 37(2), 321-328.

Маслова, Ю.А. (2014). Модель психологического сопровождения инклюзивного обучения детей с нарушенным слухом [The model of psychological support for inclusive teaching for children with hearing impairment]. Российский психологический журнал, 11(1), 24-32.

Пешкова, Н.А. (2016). Развитие межличностных отношений у слабослышащих младших школьников [The development of interpersonal relationships in hearing impaired primary school pupils]. Акмеология, 1(57), 155-158.

Полешко, Р.В. (2018). Особенности организации инклюзивного образования детей с нарушениями слуха [Characteristics of the organization of inclusive education for children with hearing impairment]. Проблемь современного педагогического образования, (59-1), 281-284. 
Речицкая, Е.Г. \& Хедхуд., Н. (2014). Комплексный подход в создании здоровьесберегающей среды в обучении и воспитании детей с нарушениями слуха [An integrated approach to creating a healthy environment in the education of children with hearing impairments]. Наука и школа, 3, 59-64.

Салимова, Ф.М. (2016). Особенности работы с детьми с ограниченными возможностями здоровья в общеобразовательных учреждениях [Characteristics of working with children with disabilities in educational institutions]. Отечественная и зарубежная педагогика, $4(31), 156-163$.

Сигал, Н.Г. (2014). Проблема профессиональной подготовки педагогов инклюзивного образования за рубежом [The problem of professional retraining of teachers for inclusive education abroad]. Современные концепции и технологии гарантированного качества высшего образования: сборник статей участников Международной научнопрактической конференции, 26-28 июня 2014, под ред. В.И. Андреева. Казань: Изд-во Казанского ун-та, 228-232.

Хафизуллина, И.Н. (2008). Формирование инклюзивной компетентности будущих учителей в процессе профессиональной подготовки [Forming inclusive competence of future teachers in the process of training]: автореф. ... канд. пед. наук. Астрахань.
Хитрюк, В.В. (2012). Инклюзивная готовность как этап формирования инклюзивной культуры педагога: структурно-уров-невый анализ [Inclusive readiness as a stage in the formation of an inclusive teacher's culture]: structural-level analysis. Вестник Брянского государственного университета, 1, 8-84.

Шумиловская, Ю.В. (2011). Подготовка будущего учителя к работе с учащимися в условиях инклюзивного образования [Preparing a future teacher to work with students in an inclusive education environment]: автореф . дис ... . . канд .пед .наук. Шуя.

Щурова, Ю.Е. (2016). Влияние нарушений слуха на интеллектуальное развитие школьников [The impact of hearing impairment on the intellectual development of pupils]. Казанский педагогический журнал, 6(119), 143-146.

Яковлева, И.М. (2013) Личностная готовность педагогов к работе с детьми, имеющими ограниченные возможности здоровья [Personal readiness of teachers to work with children with disabilities]. Коррекционная педагогика: теория и практика., 3(49), 17-21. 